\title{
Exposure to Entrepreneurial Activities and the Development of Entrepreneurial Culture
}

\author{
Christabel Divine Brownson \\ Faculty of Social and Management Sciences \\ Akwa Ibom State University, \\ P.M.B. 1167, Uyo, Akwa Ibom State, Obio Akpa Campus \\ Oruk Anam, Akwa Ibom State, Nigeria
}

\begin{abstract}
Exposure to prior entrepreneurial activities has been found by many studies to influence people's mindset towards starting their own businesses. However, while much research on exposure to prior entrepreneurial activities have been carried out in terms of family businesses, limited research have focused on the use of entrepreneurial exposures through trade fairs and entrepreneurial events carried out by government agencies to aid the development of entrepreneurial culture. Using a descriptive study, 195 participants of entrepreneurship programmes offered by the government in Akwa Ibom, Nigeria were examined and findings reveal that to a large extent, exposing individuals to entrepreneurial activities using trade fairs and entrepreneurial events does aid in the development of entrepreneurial culture in Akwa Ibom, Nigeria. The findings contribute new knowledge to the entrepreneurship literature in terms of the use of trade fairs and entrepreneurship events to stimulate business startups.
\end{abstract}

Keywords: Entrepreneurial Activities, Entrepreneurial Behaviour, Entrepreneurial Culture.

\section{INTRODUCTION}

Entrepreneurial Culture is a society that depicts the exhibition of entrepreneurial attributes, entrepreneurial values, entrepreneurial mindset and entrepreneurial behavior among the citizens of such a society which propels them towards entrepreneurship (Brownson, 2013). Given various government interest in the promotion of entrepreneurship to reduce the rate unemployment, can such a society as described above be developed through the use of trade fairs and entrepreneurial events?

Exposure to prior entrepreneurial activities has been found by many studies to influence people's mindset towards starting their own businesses (Peterman and Kennedy, 2003). Many researchers have indicated that prior family business exposures constitute a powerful socializing influence on the values, mindset, and behaviours people adopt over the course of their lives (Carr and Sequeira, 2007). Krueger (1993b) asserted that a family firm should strongly influence its family members in their perceptions of entrepreneurship. In his work of 1989, he pointed out that entrepreneurial mindsets and intentions are significantly linked to broad measures of exposure to small or new ventures. He further highlighted the usefulness of Shapero's process model of decision to initiate a new venture which argued that exposure to entrepreneurship is one potential influence resulting in situational intentions and attitudes toward entrepreneurship. Drawing furthermore from Self-efficacy theory, Krueger (1993b) asserted that limited experiences with entrepreneurship may substantially influence how one 
thinks about entrepreneurship. Citing from Elder (1991), Krueger (ibid) enumerated that entrepreneurial attributes change overtime especially in a course of important life event hence prior exposures can influence attributes.

Krueger (1993a) also acknowledged that prior entrepreneurship related experiences should influence entrepreneurial intention indirectly through the perceptions of feasibility and desirability. He found support that the feasibility element of attitude was significantly associated with breadth of prior exposure and desirability element of attitude was significantly associated with the positiveness of that prior exposure. Carr and Sequeira (2007) found significant direct and indirect effects of prior family business exposure on entrepreneurial intent, through the mediation variables of attitude towards business ownership, perceived family support and entrepreneurial self-efficacy. Krueger (1993b) found support for his hypotheses that exposure to family business raises intentions to start a venture; he found support that exposure influences positive attitudes towards entrepreneurship, he confirmed that exposure leads to significant differences in entrepreneurial attributes thus concluding that exposure to entrepreneurial activity does seem to change people (pp.83).

Although Drennan et al.'s (2005) finding was contrary to Krueger's (1993a) study, they however concluded that family business influences may only increase the attractiveness of self-employment but not necessarily the feasibility. However, while these studies have mainly focused on entrepreneurial exposures in relation to a family member, relative, friends or working in someone else's business, the focus in this study is on the entrepreneurial exposure activities of the government via its agencies to promote entrepreneurship. These activities involve the use of mix of instruments such as the media. Lundstrom and Stevenson (2005) have pointed out that the use of entrepreneurial events and trade fairs as forms of exposure to entrepreneurial activities can aid in the fostering of Entrepreneurial Culture.

\section{METHODS}

A pilot test was first undertaken in three government agencies in Akwa Ibom State to investigate the types of entrepreneurial exposures used by the agencies in the entrepreneurship promotional measures. Thereafter, a posttest- only design with nonequivalent groups was later used in the study due to its suitability in settings that does not lend itself for experiments (Agodini and Dynarski, 2004). Using purposive sampling method with a structured questionnaire, data was collected from 195 respondents who participated in the government entrepreneurship programmes. Descriptive statistics was used to analyze the data.

\section{Preliminary findings from the Agencies}

The findings from the pilot study of the agencies showed that the three agencies were involve in exposing individuals to different forms of entrepreneurial activities as shown on table 1 on the next page.

Was collected from 195 respondents who participated in the government entrepreneurship programmes. Descriptive statistics was used to analyze the data. The agencies exposed individuals in the state to various entrepreneurial activities such as; trade fairs, hands on workshops/seminars, business events, excursions and exhibitions. Individuals were made aware of these events through the state (Akwa Ibom State Broadcasting Corporation -AKBC) television, radio, newspaper, seminars, and banners among others. 
Table 1: Exposure to Entrepreneurial Activities by Government Agencies

\begin{tabular}{|c|c|c|c|}
\hline & Agency A & Agency B & Agency C \\
\hline $\begin{array}{l}\text { Exposure of } \\
\text { individuals to } \\
\text { Entrepreneurial } \\
\text { Activities }\end{array}$ & Yes & Yes & Yes \\
\hline $\begin{array}{l}\text { Type of } \\
\text { entrepreneurial } \\
\text { activities } \\
\text { individuals are } \\
\text { expose to }\end{array}$ & $\begin{array}{l}\text { Trade fairs, Hands on } \\
\text { Workshops/Seminars, } \\
\text { letters/phone }\end{array}$ & $\begin{array}{l}\text { Business events, Trade } \\
\text { fairs, Hands on } \\
\text { Workshops/Seminars, } \\
\text { Visitation to business } \\
\text { facility (Excursions) and } \\
\text { Exhibitions }\end{array}$ & $\begin{array}{l}\text { Business events, Hands } \\
\text { on } \\
\text { Workshops/Seminars, } \\
\text { and Excursions }\end{array}$ \\
\hline $\begin{array}{l}\text { Medium used to } \\
\text { contact } \\
\text { individuals for } \\
\text { such exposures }\end{array}$ & letters/phone & $\begin{array}{l}\text { AKBC TV, NTA Uyo, } \\
\text { AKBC Radio, Pioneer } \\
\text { Newspaper, Flyers, } \\
\text { Workshops/Seminars } \\
\text { and Banners }\end{array}$ & $\begin{array}{lr}\text { AKBC TV, AKBC Radio, } \\
\text { Pioneer Newspaper, } \\
\text { Flyers r and } \\
\text { workshop/Seminars }\end{array}$ \\
\hline
\end{tabular}

\section{Analysis}

The result of the descriptive analysis as shown in fig. 1 below indicates a full support for the proposition that exposure to entrepreneurial activities provided by the government agencies aids in the development of the constituent of Entrepreneurial Culture. The result shows that individuals who participated in the exposure programme agreed to the fact that the exposure to entrepreneurial activities by the agencies did to some extent contribute to the fostering of the constituent of their entrepreneurial culture since the percentage of respondents who agreed to its impact on their Entrepreneurial Attribute (62.5\%), entrepreneurial values (64.6\%), entrepreneurial mindset (71\%), and entrepreneurial behaviour $(72.2 \%)$ was a bit high compared to those who disagreed as shown on fig. 1 above. $87 \%$ of the respondents found the activities provided by the government agencies useful. This result corroborates the pilot study findings in which the respondents in the agencies agreed that the entrepreneurial activities carried out by them did aid in the nurturing of the entrepreneurial attributes (79\%), values (62\%) and mindset (80\%) of the participants of the activities. 
Fig. 1: Exposure to Entrepreneurial Activities and the Development of the Constituent of Entrepreneurial Culture

DISAGREE AGREE

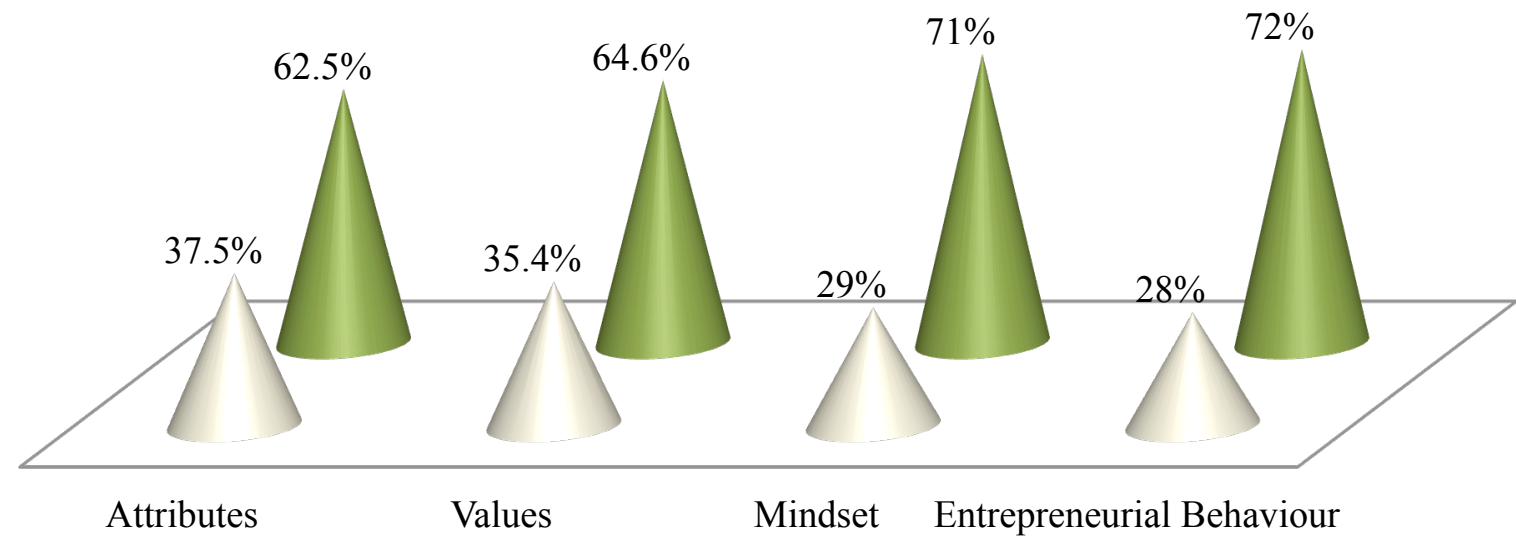

\section{DISCUSSION OF FINDINGS}

The aim of this paper was to examine the underlying assumption that exposure to entrepreneurial activities can aid in the development of the constituents of Entrepreneurial Culture with a particular focus on the exposure to entrepreneurial activities provided by the government via its agencies.

This result suggests that exposure to entrepreneurial activities may likely nurture all the constituent of entrepreneurial culture thereby tackling the unemployment situation in the state as more self-employed individuals may emerge due to the benefits derived from the policy measures. These findings are new in approach and context of the study although prior research has examined similar issue in relation to family businesses (Krueger, 1993b) hence; additional knowledge is added to the entrepreneurship literature in this respect. The findings slightly confirm Lundstrom and Stevenson's (2005) assertions that the use of entrepreneurial events and trade fairs as forms of exposure to entrepreneurial activities can aid in the fostering of entrepreneurial culture especially as shown by the findings in the descriptive analysis.

The finding of the relationship between exposure to entrepreneurial activities and entrepreneurial attributes confirms Krueger's (1993b) assertion that exposure leads to significant differences in entrepreneurial attributes thus changing people. The finding of the relationship between exposure to entrepreneurial activities and entrepreneurial values corroborates Carr and Sequeira (2007) who reported that prior family business exposure constituted a powerful socializing influence on the values people adopt over the course of their lives. This implies that over the course of the participants' lives within the period under study, there is the likelihood for them to have a change of their entrepreneurial values due partly to the exposures they have received from the policy measures organized by the government agencies. The finding of the relationship between exposure to entrepreneurial activities and entrepreneurial mindset corroborates Schwarz et al. (2009), Peterman and Kennedy (2003), Car and Sequiera (2007) and Krueger (1993b) who reported that exposure to entrepreneurial activities influences people's attitude towards starting their own businesses. The findings of the relationship between exposure to entrepreneurial activities and entrepreneurial behaviour is a new finding and contributes to the entrepreneurship literature in that there is that 
possibility that exposure to entrepreneurial activities may likely influence participants of such activities to start their own business.

\section{CONCLUSION}

The objective of this study was to examine how exposing individuals to entrepreneurial activities carried out by government agencies could aid nurture their entrepreneurial culture. Through the descriptive analysis used, it can be concluded that exposure to entrepreneurial activities does to some extent aid in the nurturing of entrepreneurial culture of individuals who participates in such exposures. The result of the analysis did to some extent confirm the pilot findings from the agencies responsible for the implementation thereby adding credibility to the findings of the analysis. The findings add new knowledge to both the entrepreneurship and public policy literature in that, government intervention to promote entrepreneurship is not a wasted effort but should be encouraged and appropriately planned and executed.

It can thus be concluded that from the descriptive perspective, exposure to entrepreneurial activities does to some extent contribute to the fostering of participants' entrepreneurial attributes, values, mindset and behavior which are the constituent of entrepreneurial culture.

\section{References}

Agodini, R. and Dynarski, M. (2004) ARE EXPERIMENTS THE ONLY OPTION? Review of Economics \& Statistics, Feb2004, Vol. 86 Issue 1, p180-194, 15p

Brownson, 2013

Carr, J. C. and Sequeira, J. M. (2007) Prior Family Business Exposure as intergenerational Influence and Entrepreneurial Intent: A Theory of Planned Behaviour Approach, Journal of Business Research, 0ct2007, Vol. 60 Issue 10, p1090-1098, 9p

Drennan J., Kennedy, J. and Renfrow, P. (2005) Impact of Childhood Experiences on The Development of Entrepreneurial Intentions, International Journal of Entrepreneurship \& Innovation, Nov2005, Vol. 6 Issue 4, p231-238, 8p;

Krueger, N. (1993) The Impact of Prior Entrepreneurial Exposure on Perceptions of New Venture Feasibility and Desirability, Entrepreneurship: Theory \& Practice, Fall93, Vol. 18 Issue 1, p5-21, 17p,

Krueger, N. F. (1993b) "Growing Up Entrepreneurial?": Developmental Consequences of Early Exposure to Entrepreneurship. Academy of Management Best Papers Proceedings, 1993, p80-84, 5p

Lundström, A. and Stevenson, L. (2005) Entrepreneurship Policy: Theory and Practice, New York: Springer, c2005

Peterman, N. E. and Kennedy, J. (2003) Enterprise Education: Influencing Students' Perceptions of Entrepreneurship. Entrepreneurship: Theory \& Practice, Winter2003, Vol. 28 Issue 2, p129-144, 16p 